\title{
Lethal exposure times and preconditioning to upper temperature limits of some temperate North Atlantic red algae
}

\author{
C. Yarish ${ }^{1}$, H. Kirkman ${ }^{2}$ \& K. Lüning ${ }^{3}$ \\ ${ }^{1}$ Department of Ecology and Evolutionary Biology, University of Connecticut; Scofield- \\ town Road, Stamford, CT 06903, USA \\ ${ }^{2}$ CSIRO, Marine Laboratories; P.O. Box 20, North Beach, W.A. 6020, Australia \\ ${ }^{3}$ Biologische Anstalt Helgoland (Zentrale); Notkestr. 31, D-2000 Hamburg 52, FRG
}

\begin{abstract}
Using the red alga Polyneura hilliae as an example, the minimum time taken for lethal temperature exposure, with no regeneration capacity left, was 2 weeks. Employing this exposure time, the upper temperature limits of the following 13 red algal species belonging to four biogeographical distribution groups were determined: Callophyllis laciniata, Polyneura hilliae, Hypoglossum hypoglossoides, Halurus equisetifolius, Lomentaria articulata, Cryptopleura ramosa, Calliblepharis ciliata (warm-temperate Mediterranean-Atlantic group); Callithamnion tetragonum, Lomentaria orcadensis (amphiatlantic-temperate group); Grinnellia americana, Lomentaria baileyana, Agardhiella subulata (northeast American tropical-temperate group), Solieria tenera (amphiatlantic tropical-temperate group). Pre-incubation temperatures of 10 and $20^{\circ} \mathrm{C}$ for one month (or 15 and $25^{\circ} \mathrm{C}$ for the two last-mentioned distribution groups) did not measurably affect the critical survival temperature.
\end{abstract}

\section{INTRODUCTION}

Investigators who have attempted to correlate the temperature requirements for survival of benthic marine algae with their phytogeographic distribution have employed differing exposure times to limiting temperatures. To give a few examples, Montfort et al. (1957) used 3 h, Biebl (1958, 1962) 12 h, Lüning (1984) 1 week, Bolton (1983) 3 weeks, McLachlan \& Bird (1984), Yarish et al. (1984, 1986) 5 weeks, and Cambridge et al. (1984) 2 months. The first objective of the present paper was to provide a complete time series at least for one alga in order to obtain some idea about the minimum exposure time after which the upper lethal temperature remains constant for the next few months.

The second objective concerned another uncertainty of the experimentator, namely the selection of the temperature at which algae should be kept and propagated prior to treatment at the experimental temperatures. Does pre-incubation at temperatures differing by as much as e.g. $10^{\circ} \mathrm{C}$ change the upper lethal temperature? Such cases of "nongenetic resistance adaptation" (Precht et al., 1955, 1973; Kinne, 1970) or "plastic resistance", in the terminology of Levitt (1980), have been investigated more in marine animals (e.g. Newell, 1976). The few experiments reported on marine algae (for review of the older literature see Gessner, 1970) stressed the stability of the upper lethal survival limit 
and the inability of the experimentator to shift these limits by choosing differing preincubation temperatures.

The last objective was to determine precisely, in temperature steps by $1{ }^{\circ} \mathrm{C}$, the upper survival limits of 13 species of red algae. For these the phytogeographic boundaries, temperature demands for growth and reproduction, and the survival limits in temperature steps by $5^{\circ} \mathrm{C}$ have been presented earlier (Yarish et al., 1984, 1986).

\section{MATERIAI AND METHODS}

The inocula for experimentation consisted of cloned cultures (cf. Yarish et al., 1984, 1986 for collection data) and were propagated at $15^{\circ} \mathrm{C}$ in von Stosch's enriched seawater medium (Ott, 1966) having a salinity of $33 \%$. Standard light conditions: cool fluorescent light, photon fluence rate of $30 \mu \mathrm{mol} \mathrm{m} \mathrm{m}^{-2} \mathrm{~s}^{-1}, 16 \mathrm{~h}$ light per day. Tests on temperature survival were performed, as described in detail by Lüning et al. (1987). In short, isolates (0.2-0.3 $\mathrm{g}$ fresh weight) were incubated in Plexiglas cylindrical jars (140 ml of culture medium; Von Stosch's Enriched Seawater at half strength; cf. Guiry \& Cunningham, 1984) contained in illuminated bath-cryostat units. The culture medium was replaced automatically once a day. After a standard treatment of 2 weeks the plants were postincubated under good growing conditions $\left(15^{\circ} \mathrm{C}\right)$ for 4 weeks to check for survival and for regenerated thalli from a few living cells in the otherwise bleached tissue. In cases where there had been any doubt about the viability of the treated material, the post-incubation was prolonged for another 4 weeks.

\section{RESULTS AND DISCUSSION}

The survival responses of the gametophytes of Polyneura hilliae are given for a period of up to 56 days (Table 1) at temperatures of $20,24-30^{\circ} \mathrm{C}$. After a six-hour

Table 1. Survival responses of Polyneura hilliae gametophytes over eight weeks. xxx plants alive (with sight observation and confirmation after 4 weeks post-incubation at $15^{\circ} \mathrm{C} ;$ reg. regeneration of purportedly "dead" tissue after four weeks at $15^{\circ} \mathrm{C}_{\mathbf{i}}-\cdots$ plants dead

\begin{tabular}{|c|c|c|c|c|c|c|c|c|}
\hline \multicolumn{9}{|c|}{ Temperature over eight weeks $\left({ }^{\circ} \mathrm{C}\right)$} \\
\hline Time (d) & 20 & 24 & 25 & 26 & 27 & 28 & 29 & 30 \\
\hline $1 / 4$ & $\mathbf{x x x}$ & $x \times x$ & $x x x$ & $x \mathrm{xx}$ & reg. & reg. & $\cdots$ & .. \\
\hline 1 & $\operatorname{xax}$ & $x \mathbf{x x}$ & $x x x$ & $x x x$ & reg. & $\cdots$ & $\cdots$ & $\ldots$ \\
\hline 2 & $\mathbf{x x x}$ & $x \mathbf{x x x}$ & $\mathbf{x x x}$ & reg. & $\cdots$ & $\cdots$ & $\cdots$ & - . \\
\hline 3 & $x \mathbf{x x}$ & $x \times x$ & $\mathbf{x x x}$ & reg. & $\cdots$ & $\cdots$ & $\cdots$ & -. \\
\hline 5 & $x x x$ & $x x x$ & $x \times x$ & reg. & $\cdots$ & $\cdots$ & $\cdots$ & - - \\
\hline 7 & $x \mathbf{x x}$ & $x 00 x$ & reg. & $\cdots$ & -. & $\cdots$ & - . & - . \\
\hline 10 & $x \times x$ & $x \times x$ & reg. & $\cdots$ & $\cdots$ & $\cdots$ & $\cdots$ & $\cdots$ \\
\hline 14 & $\mathrm{xxx}$ & $\mathbf{x x x}$ & $\cdots$ & $\cdots$ & $\cdots$ & $\cdots$ & $\cdots$ & ... \\
\hline 21 & $\operatorname{xox}$ & $x \mathbf{x x}$ & $\cdots$ & $\cdots$ & ... & $\cdots$ & $\cdots$ & $\cdots$ \\
\hline 28 & $x x x$ & $x \times x$ & $\cdots$ & $\cdots$ & $\cdots$ & $\cdots$ & $\cdots$ & $\cdots$ \\
\hline 37 & $\mathbf{x x x}$ & $\mathbf{x x x}$ & $\cdots$ & $\cdots$ & $\cdots$ & $\cdots$ & $\cdots$ & $\cdots$ \\
\hline 42 & $x \mathbf{x x}$ & $\operatorname{xxx}$ & $\cdots$ & $\cdots$ & $\cdots$ & $\cdots$ & $\cdots$ & $\cdots$ \\
\hline 56 & $x \times x$ & $\mathbf{x x x}$ & $\cdots$ & $\cdots$ & $\cdots$ & $\cdots$ & $\cdots$ & $\cdots$ \\
\hline
\end{tabular}


Table 2. Upper survival temperature and geographical boundaries of selected temperate North Atlantic red algae. Exposure time to experimental temperatures was 2 weeks. Temperature values in brackets following the geographical boundaries indicate the mean August isotherms (according to Sverdrup et al., 1942) of the surface seawater at the corresponding locations. Nomenclature according to South \& Tittley (1986). ${ }^{1}$ restricted to shallow embayments where summer temperatures exceed $17^{\circ} \mathrm{C}$ thereby permitting growth and reproduction Pre-incubation temperatures: Distribution groups 1 and 2: continuously at $15^{\circ} \mathrm{C}\left({ }^{\circ}\right)$; transferred for one month to 10 or $15^{\circ} \mathrm{C}\left({ }^{\circ} *\right.$; identical upper survival temperature). Distribution groups 3 and 4 : continuously at $20^{\circ} \mathrm{C}\left({ }^{* * *}\right)$, or transferred for one month to 20 or $25^{\circ} \mathrm{C}\left({ }^{\circ} \cdots\right.$; identical upper survival temperature)

\begin{tabular}{|c|c|c|c|}
\hline Species & $\begin{array}{l}\text { Northern } \\
\text { boundary }\end{array}$ & $\begin{array}{l}\text { Southern } \\
\text { boundary }\end{array}$ & $\begin{array}{c}\text { Upper survival } \\
\text { temperature }\left({ }^{\circ} \mathrm{C}\right)\end{array}$ \\
\hline \multicolumn{4}{|c|}{ (1) Warm-temperate Mediterranean-Atlanticgroup } \\
\hline $\begin{array}{l}\text { Callophyllis laciniata } \\
\text { (Huds.) Kütz. }\end{array}$ & $\begin{array}{l}\text { Europe } \\
\text { Norway (11) }\end{array}$ & $\begin{array}{l}\text { Europe/Africa } \\
\text { Morocco (21) }\end{array}$ & $24^{*}$ \\
\hline Polyneura hilliae (Grev.) Kylin & Ireland (14) & Portugal (19) & $24^{* *}$ \\
\hline $\begin{array}{l}\text { Hypoglossum hypoglossoides } \\
\text { (Stackh.) F. Coll. et Hervey }\end{array}$ & Shetland Is. (12) & Cameroun (27) & $25^{* \bullet}$ \\
\hline $\begin{array}{l}\text { Halurus equisetifolius } \\
\text { (Lightf.) Kütz. }\end{array}$ & Ireland (13) & Canaries (22) & $26^{*}$ \\
\hline $\begin{array}{l}\text { Lomentaria articulata } \\
\text { (Huds.) Lyngbye }\end{array}$ & Norway (11) & Madeira Is. (21) & $27^{* *}$ \\
\hline $\begin{array}{l}\text { Cryptopleura ramosa } \\
\text { (Huds.) Kylin ex Newton }\end{array}$ & Faeröes (11) & Madeira Is. (21) & $27^{* *}$ \\
\hline \multirow{2}{*}{$\begin{array}{l}\text { Calliblepharis ciliata } \\
\text { (Huds.) Kütz. }\end{array}$} & Ireland (14) & Portugal (19) & $27^{* *}$ \\
\hline & $\begin{array}{l}\text { Europe or } \\
\mathrm{N} \text {. America }\end{array}$ & $\begin{array}{l}\text { Europe/Africa or } \\
\text { N. America }\end{array}$ & \\
\hline \multicolumn{4}{|c|}{ (2) Amphiatlantic-temperategroup } \\
\hline $\begin{array}{l}\text { Callithamnion tetragonum } \\
\text { (With.) S. F. Gray }\end{array}$ & $\begin{array}{l}\text { Iceland (10) } \\
\text { Norway (10) } \\
\text { Newfdl. (12) }\end{array}$ & $\begin{array}{l}\text { Madeira Is. (21) } \\
\text { Virginia (25) }\end{array}$ & $25^{*}$ \\
\hline $\begin{array}{l}\text { Lomentaria orcadensis } \\
\text { (Harvey) F. Collins ex W. Tayl. }\end{array}$ & $\begin{array}{l}\text { Iceland (10) } \\
\text { Norway (10) } \\
\text { Nova Scotia (15) }\end{array}$ & $\begin{array}{l}\text { Portugal (20) } \\
\text { N. Carolina (25) }\end{array}$ & $27^{* *}$ \\
\hline \multicolumn{4}{|c|}{ (3) Northeast Americantropical-temperategroup } \\
\hline $\begin{array}{l}\text { Grinnellia americana } \\
\text { (C. Ag.) Harvey }\end{array}$ & Massachusetts (17) & $\begin{array}{l}\text { Tropical margins } \\
\text { (Florida) }\end{array}$ & $31 * *$ \\
\hline $\begin{array}{l}\text { Lomentaria baileyana } \\
\text { (Harvey) Farlow }\end{array}$ & $\begin{array}{l}\text { s. Gulf of }(15) \\
\text { St. Lawrence }\end{array}$ & $\begin{array}{l}\text { Tropical margins } \\
\text { (s. Florida) }\end{array}$ & $33 \cdots$ \\
\hline $\begin{array}{l}\text { Agardhiella subulata } \\
\text { (C. Ag.) Kraft et Wynne }\end{array}$ & $\begin{array}{l}\text { s. Gulf of (15) } \\
\text { St. Lawrence }\end{array}$ & Tropics & $33^{* \cdots *}$ \\
\hline \multicolumn{4}{|c|}{ (4) Amphiatlantictropical-temperategroup } \\
\hline $\begin{array}{l}\text { Solieria filiformis ( }=\text { tenera) } \\
\text { (Kütz.) Gabrielson }\end{array}$ & N. Carolina (25) & Tropics & $33 \cdots * *$ \\
\hline
\end{tabular}


treatment in the water baths, temperatures exceeding $28^{\circ} \mathrm{C}$ were lethal. Plants incubated at $27-28^{\circ} \mathrm{C}$ appeared dead; however, they began to regenerate after being reincubated at $15^{\circ} \mathrm{C}$. After 1-day treatment, the regeneration capacity was further diminished to $27^{\circ} \mathrm{C}$, after treatments of $2-5$ days duration to $26^{\circ} \mathrm{C}$, and after treatment duration of 7-10 days to $25^{\circ} \mathrm{C}$. The upper survival limit at $24^{\circ} \mathrm{C}$ was constant from an exposure time of 14 days onward.

It is interesting to note that a two-week incubation period was sufficient for determining the isolates' upper survival limits and that the difference between survival and death of the complete thallus may be a matter of $1^{\circ} \mathrm{C}$ (Table 1). The precision of the technique employed must be emphasized as one-degree intervals were used for each taxon in contrast to other experiments, which are often set in $5{ }^{\circ} \mathrm{C}$ intervals. The importance of post-incubation instead of visual inspection right after the treatment cannot be over-emphasized. Post-incubation was particularly needed for Hypoglossum hypoglossoides, Lomentaria articulata, Callithamnion tetragonum, and Polyneura hilliae, as each was able to regenerate entire thalli from only a few cells. It is suggested for future research in the determination of the upper lethal limits of algal taxa that a $5^{\circ} \mathrm{C}$ interval should be established encompassing the lethal temperature. After the interval has been found out, then the precise lethal limit should be determined by incubation at $1{ }^{\circ} \mathrm{C}$ intervals for at least two weeks with frequent change of.culture medium.

Table 2 exhibits the survival responses of all investigated algal species. The upper survival limits of the warm-temperate species (groups 1 and 2 in Table 2) range at $24-27^{\circ} \mathrm{C}$, whereas species with tropical affinities (groups 3 and 4 ) are clearly differentiated by values ranging at $31-33^{\circ} \mathrm{C}$.

Nine out of the 13 species investigated were tested after pre-incubation for one month at temperatures differing by $10^{\circ} \mathrm{C}$ (Table 2). Identical values for the upper survival temperature were obtained in all cases. Apparently, the isolates had no ability to shift their upper lethal temperature. This is in accordance with results reported for most of the smaller marine algal species from Helgoland, whereas seasonal shifts of upper temperature tolerance were readily detected in larger algae, e.g. Laminaria spp. and Desmarestia aculeata (Lüning, 1984 and older literature cited herein). During the cold season, these algae form new, heat-sensitive tissue, which subsequently "hardens" and exhibits a $2-5^{\circ} \mathrm{C}$ higher temperature tolerance in summer. It may well be possible that in smaller algae the youngest cells are more heat-sensitive and that this effect is easily overlooked for technical reasons, because in larger algae one can easily treat old and young tissue separately. The upper survival temperatures listed in Table 2 cannot be directly related to the positions of the species' southern limits, as other factors (e.g. temperatures limiting growth and/or reproduction) may be important. Moreover, extreme temperature values are more important than average values (see Yarish et al., 1984, 1986).

Acknowledgements. The authors thank P. Kadel for her invaluable technical assistance. C. Yarish and $H$. Kirkman are indebted to the Director of the Biologische Anstalt Helgoland for his hospitability and working facilities. Thanks are also due to Prof. C. van den Hoek for helpful suggestions in regard to the manuscript. C. Yarish is also indebted to support from the Connecticut Sea Grant Program. 


\section{LITERATURE CITED}

Biebl, R., 1958. Temperatur- und osmotische Resistenz von Meeresalgen der bretonischen Küste. Protoplasma 50, 217-242.

Biebl, R., 1962. Temperaturresistenz tropischer Meeresalgen. - Botanica mar. 4, 241-254.

Bolton, J. J., 1983. Ecoclinal variation in Ectocarpus siliculosus (Phaeophyceae) with respect to temperature growth optima and survival limits. - Mar. Biol. 73, 131-138.

Cambridge, M., Breeman, A. M., Oosterwyk, R. \& Hoek, C. van den, 1984. Temperature responses of some N. Atlantic Cladophora species (Chlorophyceae) in relation to their geographic distribution. - Helgoländer Meeresunters. 38, 349-363.

Gessner, F., 1970. Temperature. Plants. In: Marine ecology. Ed. by O. Kinne. Wiley-Interscience, London, 1 (1), 363-406.

Guiry, M. D. \& Cunningham, E. M., 1984. Photoperiodic and temperature responses in the reproduction of north-eastern Atlantic Gigartina acicularis (Rhodophyta: Gigartinales). - Phycologia 23, 357-367.

Kinne, O., 1970. Temperature: Animals: Invertebrates. In: Marine ecology. Ed. by O. Kinne. WileyInterscience, London, 1 (1), 407-514.

Levitt, J., 1980. Responses of plants to environmental stress. Acad. Press, New York, 1, 1-497.

Lüning, K., 1984. Temperature resistance and biogeography of seaweeds: the marine algal flora of Helgoland, North Sea, as an example. - Helgoländer Meeresunters. 38, 305-317.

Lüning, K., Guiry, M. D. \& Masuda, M., 1987. Upper temperature tolerance of North Atlantic and North Pacific geographic isolates of the red algae Chondrus. - Helgoländer Meeresunters. 41, 297-306.

McLachlan, J. \& Bird, C. J., 1984. Geographical and experimental assessment of the distribution of species of Gracilaria in relation to temperature. - Helgoländer Meeresunters. 38, 319-334.

Montfort, C., Ried, A. \& Ried, I., 1957. Abstufungen der funktionellen Wärmeresistenz bei Meeresalgen in ihren Beziehungen zu Umwelt und Erbgut. - Biol. Zbl. 76, 257-289.

Newell, R. C. (Ed.), 1976. Adaptation to the environment: essays on the physiology of marine animals. Butterworths, London, $539 \mathrm{pp}$.

Ott, F. D., 1966. A selected listing of axenic algal cultures. - Coll. Repr. Woods Hole Oceanogr. Instn $72,1-20$.

Precht, H., Christophersen, J. \& Hensel, H., 1955. Temperatur und Leben. Springer, Berlin, 514 pp.

Precht, H., Christophersen, J., Hensel, H. \& Larcher, W. (Eds), 1973. Temperature and life. Springer, Berlin, 779 pp.

South, G. R. \& Tittley, I., 1986. A checklist and distributional index of the benthic marine algae of the North Atlantic Ocean. Huntsman Marine Laboratory, St. Andrews, 76 pp.

Sverdrup, H. U., Johnson, M. W. \& Fleming, R. H., 1942. The oceans. Prentice Hall, Englewood Cliffs, N. J., $1060 \mathrm{pp}$.

Yarish, C., Breeman, A. M. \& Hoek, C. van den, 1984. Temperature, light and photoperiod responses of some Northeast American and West European endemic rhodophytes in relation to their geographical distribution. - Helgoländer Meeresunters. 38, 273-304.

Yarish, C., Breeman, A. M. \& Hoek, C. van den, 1986. Survival strategies and temperature responses of seaweeds belonging to different biogeographic groups. - Botanica mar. 29, 215-230. 